\title{
Vulnerability Assessment of Water in Landfill Site and Environs: A Case Study of Olusosun in Lagos, Nigeria
}

\author{
Makinde E. O. ${ }^{1}$, Paul T. E. ${ }^{2} *$, Olatunbosun O. E. ${ }^{3}$ and Nwilo P. C. ${ }^{4}$ \\ ${ }^{1,2,3,4}$ Department of Surveying and Geoinformatics, University of Lagos, Akoka, Lagos state, Nigeria \\ Corresponding Author: *temmanuel565@gmail.com
}

https://doi.org/10.36263/nijest.2020.02.0165

\begin{abstract}
This study assessed the vulnerability of landfill site in Olusosun, Lagos Nigeria using modified DRASTIC (DRASTIC L) model in a geographical information system environment. It also analysed water samples with a view to determining traced metals concentrations present. Water samples were collected from different Boreholes and Wells with a radius of $500 \mathrm{~m}$ to the landfill site. The modified DRASTIC (DRASTIC L) based on eight parameters such as Depth to water, Net recharge, Aquifer media, Soil media, Topography, Impact of vadose zone, Hydraulic conductivity and Distance to landfill site. The vulnerability index was calculated using a sum overlay of the eight parameters. ArcGIS 10.2 software was used to integrate all these parameters together to obtain Boreholes and Wells vulnerable zones I areas. The results showed that out of a total of 228.38 hectares, only about 47.46 hectare was observed to be within the low vulnerable zone having a DRASTIC index range between 113 - 136; while about 130.65 hectares were found to be in the moderately vulnerable zone with a DRASTIC index ranging between 136 and 144. About 50.28 hectares were within the high vulnerability zone having a DRASTIC index range between 144 and 163. Atomic Absorption Spectroscopy (AAS) was used to test the concentration of heavy metals in the water samples collected and found that aside the presence of other heavy metals, Chromium was found to be present in most Wells and Boreholes measuring between $0.08 \mathrm{mg} / \mathrm{L}$ and $0.43 \mathrm{mg} / \mathrm{L}$ which is above the World Health Organization Standard of $0.05 \mathrm{mg} / \mathrm{L}$ for drinking water. This study concluded that the groundwater is contaminated and the level of pollution is directly related to the distance from the landfill.
\end{abstract}

Keywords: Landfill, contamination, Pollution, GIS, Vulnerability, Environment

\subsection{Introduction}

The existence of life is without the generation of waste. How these generated wastes are managed can be challenging and can have negative impact on the environment. Waste management is one of the challenging environmental problem often encounter by cities in most developing countries (Bartone $e t$ al., 1990). Certain areas are usually designated as landfill for wastes. Landfill site can be defined as the deposit of refuse or waste by tipping it on land (Allaby, 1998).Land filling of municipal solid waste is a common waste management practice today and also one of the cheapest methods for organized waste management in many parts of the world (El-Fadel et al., 1997; Dsakalopoulous et al., 1998, Jhamnani et al., 2009).

However, they pollute the environment. Leachate is a fluid which emerges from wastes on a landfill, thereby picking up a variety of suspended and dissolved materials along the way. The generation of leachate depends on the amount of liquid originally contained in the waste (primary leachate) and the quantity of precipitation that enters the landfill through the cover or that which comes in direct contact with the waste (secondary leachate) prior to being covered (Jhamnani and Singh, 2009). The concentration of contaminants, permeability of geologic strata, and the type of geologic strata and toxicity of the contaminants are factors that make groundwater polluted by leachates (Albinet and Margat, 2007). Leachate pollutes the surface and groundwater. Groundwater is a valuable resource in any part of the world; therefore, water quality is a very important groundwater management practice. However, surface water pollution is difficult to detect and control if groundwater is contaminated. 
Groundwater vulnerability or aquifer vulnerability is a function of the geological nature of a particular environment, and the most common definition of groundwater vulnerability or aquifer vulnerability is from (Urba and Zaprotec, 1994), who describe that aquifer vulnerability as a concept of representing the intrinsic properties of aquifer system as a function of their sensitivity of the resources to its environment. Groundwater reservoirs can be easily contaminated by pollution. The process of contamination may be slow, but its effect is very dreadful (Baghvand et al., 2010) which is right from the ground to the unsaturated zone. This implies whether it is physical pollution (radioactivity), chemical (mineral pollutants), organic (pesticides) (Worrali et al., 2004) and bacteriological (bacterial viruses) (Schijven et al., 2010), the aquifer is affected. Previous research (Barton et al., 1994) has shown that ground water can contain heavy metals which can be extremely toxic to humans even at low concentrations, due to the tendency of bioaccumulation in the food chain.

Lagos located in Nigeria, is one of the cities that has its groundwater prone to contamination from open waste dumps, oil spill, underground infrastructure and massive un-engine landfill site, of which Olusosun landfill site is one. This study therefore assessed the impact of Olusosun landfill on the aquifer and analyzed how vulnerable they are.

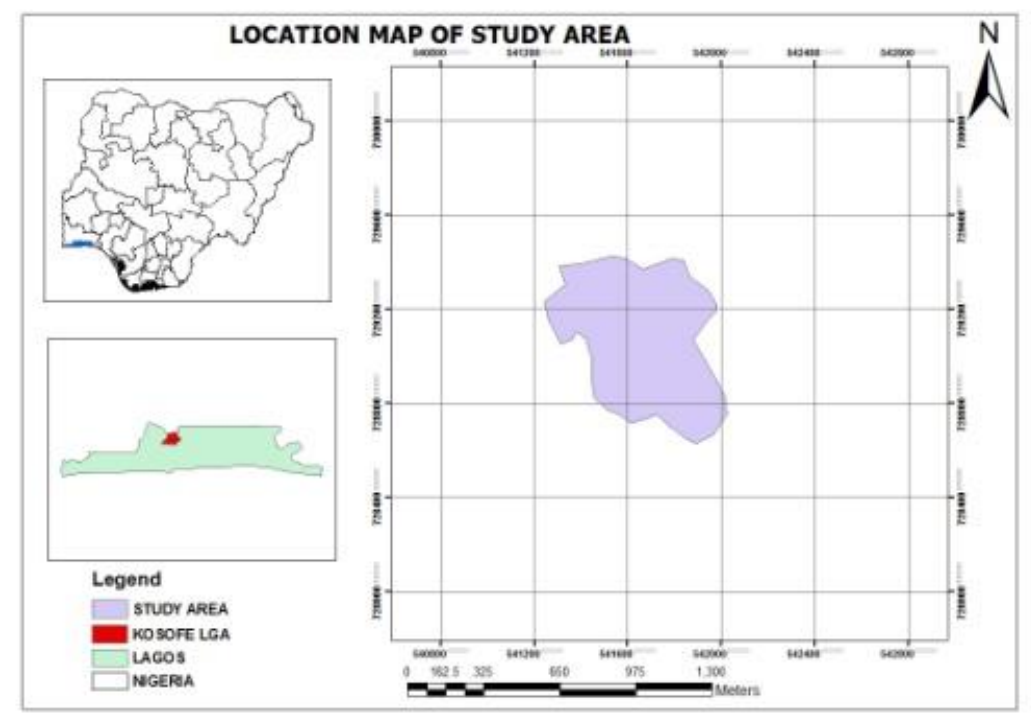

Figure 1: Map of Lagos showing Olusosun landfill in Lagos, Nigeria

\subsection{Materials and Methods}

\subsection{The study area}

Olusosun landfill site is located in Ojota area of Lagos state Nigeria (Figure 1). It was established in 1992 and covers about 42.7 hectares with an average of 1000000 tonnes of wastes been collected annually. The landfill is located between $6^{\circ} 23^{\prime} \mathrm{N} ; 2^{\circ} 42^{\prime} \mathrm{E}$ and $6^{\circ} 41^{\prime} \mathrm{N} ; 3^{\circ} 42^{\prime} \mathrm{E}$. The geology of the area is generally characterized by coastal plain sands which form the low lying, gently sloping uplands, and the coastal deposits forming extensive red earths, and loose poorly sorted sands that are mixed with an abundance of clays (World Bank, 2002). The climate of Lagos area is known to be characterized by two main seasons: wet (April - October) and dry (November - March) seasons. The highest peak of the rainfall occurs around July and September/October, and they are often accompany by floods, which effects are usually aggravated by the poor surface drainage systems. Mean annual rainfall in Lagos area varies from $1567.2 \mathrm{~mm}$ at the North West to $1750 \mathrm{~mm}$ at the mainland.

\subsection{Data acquisition and processing}

Primary and Secondary data for this study were collected from multiply sources. A GARMIN GPS was used to take GPS readings which were subsequently imported into the GIS environment. Topographical data was collected from the Surveyor General's office of Lagos state, Alausa. Meteorological data of daily and monthly rainfall for a period of 2000-2015 were collected from Nigerian Meteorological Agency (NIMET), Lagos state and Geotechnical Borehole Log was gotten 
from Ground Marks ENG. ArcGIS 10.2 software was used to process the hydrological data and produce the vulnerability maps. Modified DRASTIC (DRASTIC L) model, an index based method was used to analyze the hydrological vulnerability of Olusosun landfill site and subsequently, sensitivity analysis was performed. The DRASTIC model is characterized by the use of a high number of parameters, which is believed to limit the impact of errors and uncertainties in the individual parameters on the final output (Rosen, 1994; Babiker et al., 2005). DRASTIC is an acronym of seven hydro-geological parameters whose vulnerability tend towards pollution. These parameters are; depth to aquifer (D), recharge (R), aquifer media (A), soil type (S), topography (T), vadose zone (I), and hydraulic conductivity (C). The L is the distance. Each DRASTIC L factor was then assigned a weight $(\mathrm{w})$ based on its relative significance contribution to the pollution potential. The weight were also assigned a rating ( $\mathrm{r}$ ) for different ranges of values. These typical ratings range from $1-10$ and weights are from $1-5$ (Table 1). The weight for the depth to water was extracted from geotechnical Borehole Log from Ground Marks Engineering. Interpolation by using inverse distance weight (IDW) was carried out to covert the table to raster for effective processing in ArcGIS 10. The net recharge was determined from the annual data collected from Nigerian Meteorological Agency and used directly, while the aquifer media known as the saturated ground zone was also extracted from geotechnical borehole log. The contaminant attenuation of aquifer depends on the amount and sorting of fine grains, lower grain size higher than the attenuation capacity of aquifer media. This was represented by the equivalent permeability, which is found from Geotechnical Borehole log. The soil media data was obtain from Geotechnical Borehole log (Ground Marks Engineering) and (Solomon et al., 2016) report and the topography was obtain from the topographical map (softcopy) of the Lagos State Surveyor General's office; and the Impact of vadose zone used was obtain from Geotechnical Borehole Log (Ground Marks Engineering) and (Solomon et al., 2016) while the hydraulic conductivity was determined from (Shirazi et al., 2012). The linear distances to landfill site were determined from the measure tool in ArcGIS 10.2. The DRASTIC L index which is a vulnerability index was then calculated using Equation (1):

$D r D w+R r R w+A r A w+S r S w+T r T w+I r I w+C r C w+L r L w$

where: $D r=$ depth rating, $D w=$ depth weight, $R r=$ net recharge rating, $R w=$ net recharge weigh, $A r=$ aquifer rating, $A w=$ aquifer weight,$S r=$ soil rating, $S w=$ soil weight, $T r=$ topography rating, $T w=$ topography weight, $I r=$ impact of vadose zone rating, $I w=$ impact of vadose zone weight, $C r=$ hydraulic conductivity rating, $C w=$ hydraulic conductivity weight, $L r=$ distance rating, $L w=$ distance weight.

Each parameter map was combined together in ArcGIS 10.2 by using raster calculator tool to overlay them. The final vulnerability map was produced by adding all the "DRASTIC L" parameter and by using the raster calculator with the command "Lookup". After the DRASTIC Vulnerability index (DVI) calculation, the results were divided into three classes of High, Moderate and Low. Higher values depict greater vulnerability to groundwater contamination, medium index value represent moderate vulnerability to groundwater contamination and lower DVI values depict low vulnerability to groundwater contamination.

To test for physical ground water contamination, about 13 water samples were collected from Boreholes and Wells randomly. This was within a buffer of $500 \mathrm{~m}$ to the landfill site. The water samples were tested for trace elements such as $\mathrm{Cu}, \mathrm{Zn}, \mathrm{Cr}$ and $\mathrm{Pb}$. The analysis was carried out to compare the experimental results with the contamination vulnerability levels as shown by overall vulnerability map prepared by using the DRASTIC model. 
Table 1: Rate and weight of the eight DRASTIC L parameters

\begin{tabular}{|c|c|c|c|}
\hline DRASTIC L Parameter & Range & Ratings & DRASTIC L Weight \\
\hline \multirow[t]{6}{*}{ Depth to water (m) } & $0-2$ & 10 & 5 \\
\hline & $2-10$ & 8 & \\
\hline & $10-20$ & 6 & \\
\hline & $20-40$ & 4 & \\
\hline & $40-60$ & 2 & \\
\hline & $>60$ & 1 & \\
\hline \multirow[t]{9}{*}{ Net recharge $(\mathrm{mm} / \mathrm{yr})$} & $800-900$ & 1 & 4 \\
\hline & $901-1000$ & 2 & \\
\hline & $1001-1100$ & 3 & \\
\hline & $1101-1200$ & 4 & \\
\hline & $1210-1300$ & 5 & \\
\hline & $1301-1400$ & 6 & \\
\hline & $1401-1500$ & 7 & \\
\hline & $1501-1600$ & 8 & \\
\hline & $1601-1700$ & 9 & \\
\hline \multirow[t]{6}{*}{ Aquifer media } & Sandy clay & 1 & 3 \\
\hline & Silty sand \& sand & 2 & \\
\hline & Sand, gravel and sandy clay & 4 & \\
\hline & Sand & 6 & \\
\hline & Sandy gravel & 8 & \\
\hline & Gravel & 9 & \\
\hline \multirow[t]{8}{*}{ Soil media } & Clayey loam soil & 2 & 2 \\
\hline & Clayey soil & 3 & \\
\hline & Silty clay loam soil & 4 & \\
\hline & Silty loam & 5 & \\
\hline & Sandy clay loam soil & 6 & \\
\hline & Sandy clay soil & 7 & \\
\hline & Sandy loam soil & 8 & \\
\hline & Cliffs & 9 & \\
\hline \multirow[t]{4}{*}{ Topography } & $1-2 \%$ & 10 & 1 \\
\hline & $2-6 \%$ & 9 & \\
\hline & $6-12 \%$ & 5 & \\
\hline & $12-18 \%$ & 1 & \\
\hline \multirow[t]{3}{*}{ Impact of vadose zone } & Confined aquifer & 1 & 5 \\
\hline & Sandy clay and sand & 5 & \\
\hline & Sand & 6 & \\
\hline \multirow[t]{5}{*}{ Hydraulic conductivity } & $1 \times 10^{-6}-5 \times 10^{-5}$ & 1 & 3 \\
\hline & $5 \times 10^{-5}-2 \times 10^{-4}$ & 2 & \\
\hline & $2 \times 10^{-4}-4 \times 10^{-4}$ & 4 & \\
\hline & $4 \times 10^{-4}-5 \times 10^{-4}$ & 6 & \\
\hline & $5 \times 10^{-6}-1 \times 10^{-3}$ & 8 & \\
\hline \multirow[t]{10}{*}{ Distance from landfill site $(\mathrm{m})$} & $350-500$ & 1 & 4 \\
\hline & $500-600$ & 2 & \\
\hline & $600-700$ & 3 & \\
\hline & $700-800$ & 4 & \\
\hline & $800-900$ & 5 & \\
\hline & $900-1000$ & 6 & \\
\hline & $1000-1100$ & 7 & \\
\hline & $1100-1250$ & 8 & \\
\hline & $1250-1350$ & 9 & \\
\hline & $1350-1450$ & 10 & \\
\hline
\end{tabular}

Source: Aller et al., 1987; Jasem and Alraggad 2012; Mores s.a.rl 2010; Majolagbe et al., 2016

\subsection{Statistical and sensitivity analysis}

The results obtained were subjected to Pearson's correlation coefficient statistical analysis (Equation 2).

$r=\frac{n\left(\sum x y\right)-\left(\sum x\right)\left(\sum y\right)}{\left.\sqrt{\left[n \sum x^{2}\right.}-\left(\sum x\right)^{2}\right]-\left[n \sum y 2-\left(\sum y\right)^{2]}\right.}$

Where $x=$ a variable in the DRASTIC L parameter, $y=$ another variable in the eight parameter, $\sum x=$ sum total of $x$ DRASTIC L parameter, $\sum y=$ sum total of y variable, $\sum x^{2}=$ square of sum total $x$ 
variable, $\sum y^{2}=$ square of sum total y variable, $\sum x y=$ summation of $x$ and $y$ parameters, $N=$ number of DRASTIC L parameters (8).

The DRASTIC model is characterized by the use of high number of parameters, which is believed to limit the impact of errors and uncertainties in individual parameters on the final output (Rosen, 1994; Babiker et al., 2005). However, some authors (Barber et al., 1993; Merchant et al., 1987) have claimed that a result equivalent to DRASTIC can be obtained using a lower number of input parameters (McLay et al., 2001). Because it is not possible at present to avoid subjectivity, one way to deal with this is by performing a sensitivity analysis (Napolitano and Fabbri, 1996).

In order to remove all these doubts, two tests were performed. The first is the sensitivity analysis test of the model (Lodwick et al., 1990) and the second is the ground water contamination analysis (Napolitano and Fabbri, 1996). The sensitivity of vulnerability map is performed by removing one or more layer maps and is worked out using the following Equation (3):

$S=100 *\left(\frac{\frac{V}{N}-\frac{V^{\prime}}{n}}{v}\right)$

$V$ and $V^{\prime}$ are the unperturbed and the perturbed Vulnerability indices, respectively; $N$ and $n$ are the number of data layers used to calculate $V$ and $V^{\prime}$.

For the second test, because the DRASTIC index is highly sensitive to the parameter scores and weightings, and the numerical values assigned to its parameters are essentially arbitrary (Al-Adamat et al., 2003); therefore, single parameter sensitivity was introduced by (Napolitano and Fabbri, 1996) with which a comparison can be made between the real weight and "theoretical" weight used in DRASTIC. The real or the "effective" weight is computed by:

$W=\left(\frac{P r P w}{V}\right) * 100$

where: $W$ refers to the "effective" weight of each parameter, $P r$ and $P w$ are the rating value and the weight for each parameter and $V$ is the overall vulnerability index.

Using the "effective" weight in the DRASTIC computation could help to obtain a more realistic vulnerability map; i.e. replacing the "theoretical" weight with the calculated "effective" weight after rescaling, in the DRASTIC Equation (3).

\subsection{Ground water analysis}

The groundwater contamination analysis was carried out by taking samples of water from 13 different wells and boreholes on July 2017. For this research a plastic of 2 liter was used for water collection. After the completion of sampling task, preservation of the collected water samples was necessary to obtain good results. Therefore, pure nitric acid is necessary to add into the sample for metal ions preservation. Besides this, acidification of the collected water sample is essential below $\mathrm{pH} 2.0$ to minimize the precipitation and adsorption on container walls.

The preparation of standard solution of the various metals, standardization, data analysis and calculation were performed by taking a measured volume $(50 \mathrm{ml})$ of well mixed, acid preserved sample into a beaker. Added to it were $5 \mathrm{ml}$ conc. $\mathrm{HNO}_{3}+$ few glass beads, slowly boiled and evaporated on a hot plate for up to $10-20 \mathrm{ml}$. Conc. $\mathrm{HNO}_{3}$ (few ml) was added until the completion of digestion (sample not allowed to dry). The preparation included washing down the beaker with deionized water ( 3 times); filtering and pouring the sample in $100 \mathrm{ml}$ volumetric flask and makeup to $100 \mathrm{ml}$, then mix thoroughly. Three concentrations of standard solution of a particular metal to be analyzed were selected and the following performed: aspirate blank solution and adjust zero; and aspirate each standard solution into flame. Readings were taken from the prepared sample solution directly from the instrument and the appropriate dilution factor for the samples having higher concentration of metal ions was used. The sample water was tested for trace elements, e.g. $\mathrm{Cu}, \mathrm{Zn}, \mathrm{Cr}$ and $\mathrm{Pb}$. The analysis was carried out to compare the experimental results with the contamination 
vulnerability levels as shown by overall vulnerability map prepared by using the modified DRASTIC model.

\subsection{Results and Discussion}

\subsection{Vulnerability index}

The result of this study shows that the study covers a total area of 228.38 hectares. Out of this total, about 47.46 hectare is found to be in the low vulnerable zone and has a DRASTIC index range of from 113 - 136. About 130.65 hectares are in the moderately vulnerable zone with a DRASTIC index range between 136 and 144 . Also, about 50.28 hectares are found to be in the high vulnerability zone and its DRASTIC index range is between 144 and 163 . Thus, $21 \%$ of the study area of which 1 Well and 5 Boreholes are considered to be less vulnerable while 57\% (1 Well and 1 Borehole), are moderately vulnerable and 22\% (6 Wells and 1 Borehole) are considered to be mostly vulnerable. Findings also show that areas that are closer to the landfill sites are more.

ArcGIS 10.2 was used to produce the Maps for each parameter (Figure 2). The final vulnerability map (Figure 3) was produce by adding all the "DRASTIC L" parameters using the raster calculator with the weight and rate in focus.

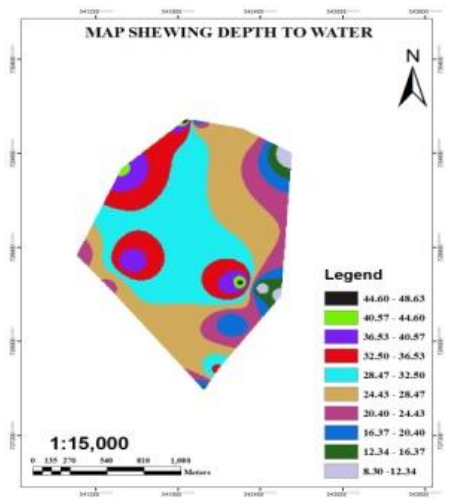

(a)

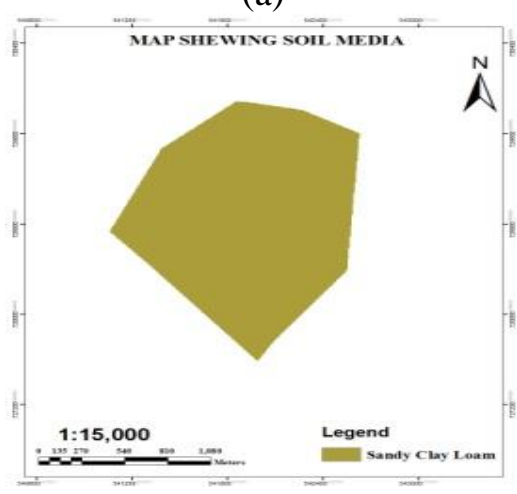

(d)

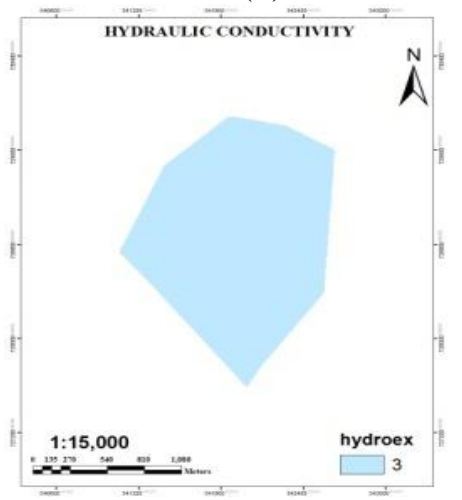

(g)

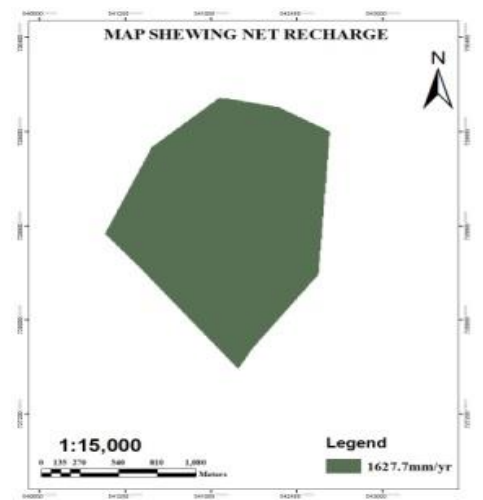

(b)

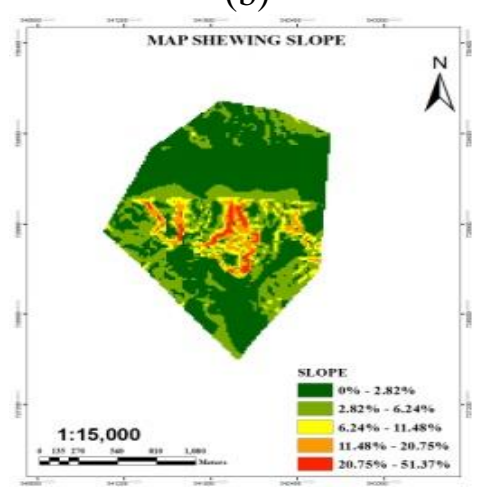

(e)

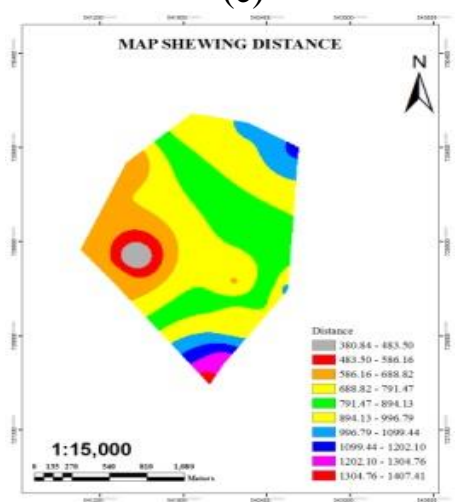

(h)

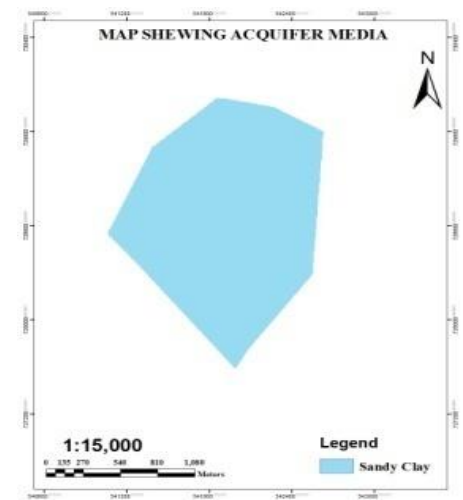

(c)

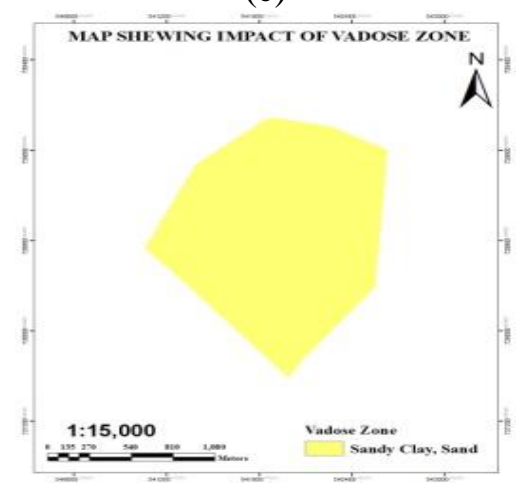

(f)

Figure 2: Maps showing (a) Depth to water, (b) Net recharge, (c) Aquifer media, (d) Soil media, (e) Slope, (f) Impact of Vadose zone, (g) Impact of Vadose zone, (h) Distance to landfill site zone 


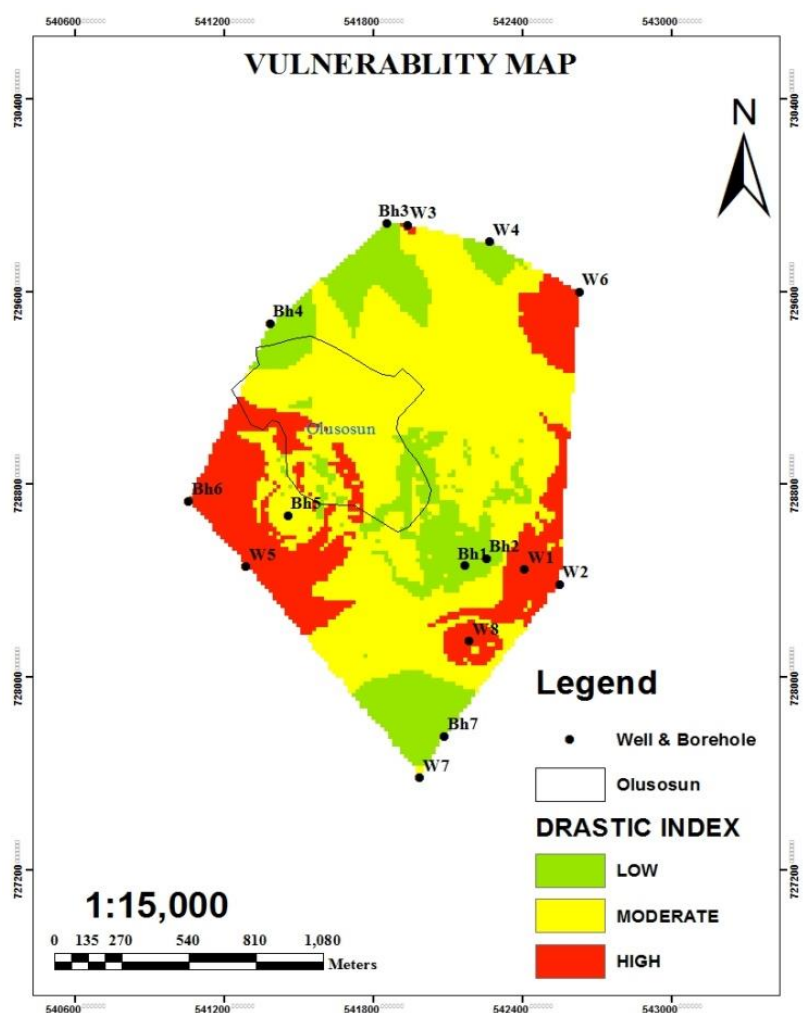

Figure 3: The Vulnerability map

\subsection{Statistical and sensitivity results}

A critical look of the statistical table (Table 2) shows that the mean parameter of Net Recharge (mean =9) contribute the highest to the vulnerability index, closely followed by soil (mean=6) though the two is one parameter data. Depth, Distance, and Topography contribute moderately to the vulnerability index while Aquifer and Hydraulic conductivity have the lowest contribution to the vulnerability index. The coefficient of variations indicates that a high contribution to the variation of vulnerability index is made by Topography $(61.4 \%)$, moderate contribution is made by Depth $(52.2 \%)$ and Distance (52.2\%) while Net Recharge, Aquifer media, Soil media, Impact of vadose zone, Hydraulic conductivity has no contribution to the variation of the vulnerability index.

Table 2: A statistical summary of the DRASTIC L parameter

\begin{tabular}{lcccccccc}
\hline & D & R & A & S & T & I & C & L \\
\hline Min & 1 & 9 & 1 & 6 & 1 & 5 & 1 & 1 \\
Max & 10 & 9 & 1 & 6 & 10 & 5 & 1 & 10 \\
Mean & 5.5 & 9 & 1 & 6 & 5.5 & 5 & 1 & 5.5 \\
SD & 2.87 & 0 & 0 & 0 & 3.44 & 0 & 0 & 2.87 \\
CV (\%) & 52.1 & 0 & 0 & 0 & 61.4 & 0 & 0 & 52.1 \\
& 8 & & & & 3 & & & 8 \\
\hline
\end{tabular}

It is clear that high variation of the vulnerability index is expected on the removal of the net recharge, $\mathrm{R}$ (mean variation index: $1.70 \%$ ). This can be attributed to the high "theoretical" weight assigned to this layer (4) and the high recharge rate derived essentially by wastewater additions to the rivers and irrigation applications in this area.

Furthermore, the vulnerability index seems to be sensitive to the removal of depth (D) as the mean variation index is $1.44 \%$, although the low real weight (18.51\%), impact of vadose zone and distance will also have a significant impact if removed. The least sensitive parameter is the aquifer media (A) of $0.14 \%$, in spite of the high "theoretical" weight assigned to it (Table 3 and 4). 
Table 3: Statistics of single parameter sensitivity analysis result

\begin{tabular}{ccccccc}
\hline \multirow{2}{*}{ Parameter } & Theoretical & Theoretical & \multicolumn{4}{c}{ Effective weight (\%) } \\
\cline { 4 - 7 } & weight & weight $(\%)$ & Mean & Min & Max & SD \\
\hline D & 5 & 18.51 & 1.44 & 0.24 & 2.37 & 1.51 \\
R & 4 & 14.81 & 1.70 & 1.70 & 1.70 & 0.00 \\
$\mathrm{~A}$ & 3 & 11.11 & 0.14 & 0.14 & 0.14 & 0.00 \\
$\mathrm{~S}$ & 2 & 7.40 & 0.57 & 0.57 & 0.57 & 0.00 \\
$\mathrm{~T}$ & 1 & 3.70 & 0.43 & 0.24 & 0.47 & 0.00 \\
$\mathrm{I}$ & 5 & 18.51 & 1.18 & 1.18 & 1.18 & 0.00 \\
$\mathrm{C}$ & 3 & 11.11 & 0.14 & 0.14 & 0.14 & 0.00 \\
$\mathrm{~L}$ & 4 & 14.81 & 1.06 & 0.19 & 1.89 & 1.21 \\
\hline
\end{tabular}

Table 4: Correlations between parameters

\begin{tabular}{l|cccccccc}
\hline & $\mathrm{D}$ & $\mathrm{R}$ & $\mathrm{A}$ & $\mathrm{S}$ & $\mathrm{T}$ & $\mathrm{I}$ & $\mathrm{C}$ & $\mathrm{L}$ \\
\hline $\mathrm{D}$ & 1.00 & & & & & & & \\
$\mathrm{R}$ & 0.00 & 1.00 & & & & & & \\
$\mathrm{~A}$ & 0.00 & 0.00 & 1.00 & & & & & \\
$\mathrm{~S}$ & 0.00 & 0.00 & 0.00 & 1.00 & & & & \\
$\mathrm{~T}$ & -0.10 & 0.00 & 0.00 & 0.00 & 1.00 & & & \\
$\mathrm{I}$ & 0.00 & 0.00 & 0.00 & 0.00 & 0.00 & 1.00 & & \\
$\mathrm{C}$ & 0.00 & 0.00 & 0.00 & 0.00 & 0.00 & 0.00 & 1.00 & \\
$\mathrm{~L}$ & -0.50 & 0.00 & 0.00 & 0.00 & -0.17 & 0.00 & 0.00 & 1.00 \\
\hline
\end{tabular}

\subsection{Groundwater analysis result}

Figures 4 to 7 shows the results of the concentration of heavy metals in the Well and Boreholes with $500 \mathrm{~m}$ radius of the landfill site. It was observed from the findings of the water analysis that the concentration of Zinc ( $\mathrm{Zn})$ in Borehole 6 is $5.48 \mathrm{mg} / \mathrm{L}$. This is above the Nigerian Standards for Drinking Water Quality (NSDWQ) standard of $3.0 \mathrm{mg} / \mathrm{L}$ (Table 5). This agrees with the vulnerability map that indicated Borehole 6 as being highly vulnerable. Borehole 3, 1 and 7 are within the low vulnerability index and are not beyond the WHO and NSDWQ standard.

Although for Copper $(\mathrm{Cu})$, water samples result in both Wells and Boreholes do not exceed WHO and NSDWQ standard of $2.0 \mathrm{mg} / \mathrm{L}$ and $1.0 \mathrm{mg} / \mathrm{L}$ respectively, Borehole 6 and Well 3 are still high. The concentration of Lead $(\mathrm{Pb})$ in Well 8 is $0.04 \mathrm{mg} / \mathrm{L}$. This is above the WHO and NSDWQ standard of $0.01 \mathrm{mg} / \mathrm{L}$. Also, this finding agrees with the vulnerability map where Well 8 was observed to be highly vulnerable. It was discovered that the concentration of Chromium $(\mathrm{Cr})$ was above the acceptable standard in most of the Wells and Boreholes (Table 5).

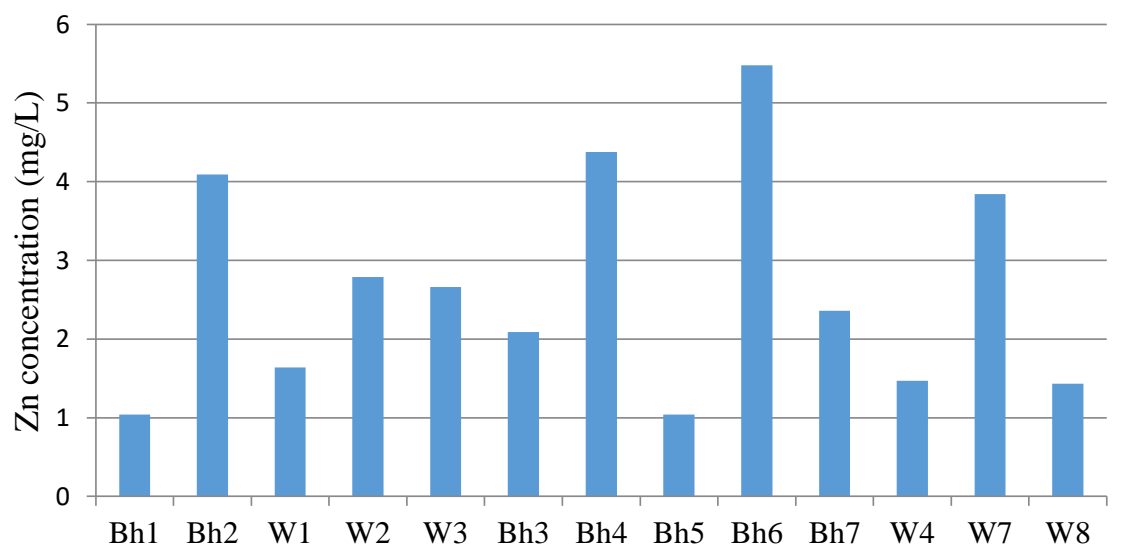

Figure 4: Zinc concentrations in different boreholes and wells 


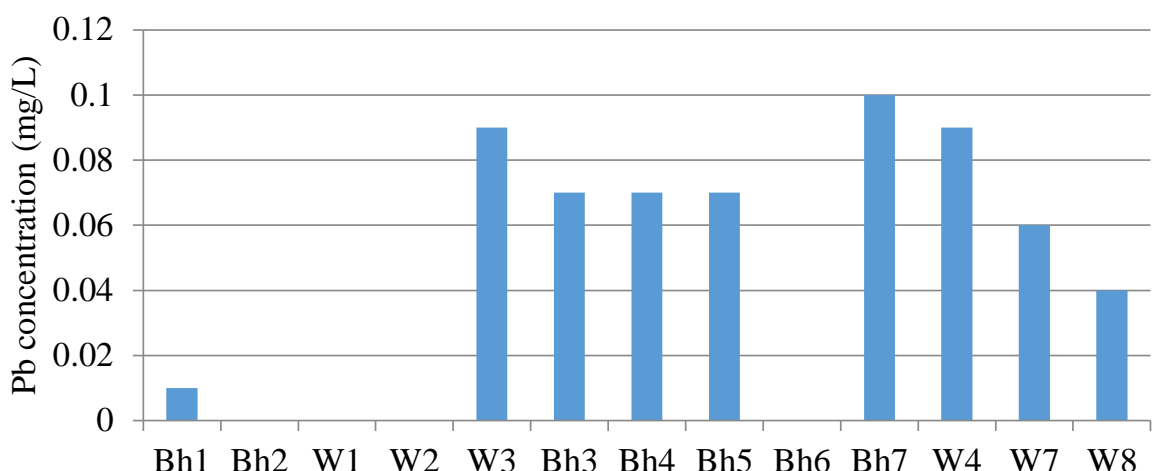

Figure 5: Lead concentrations in different boreholes and wells

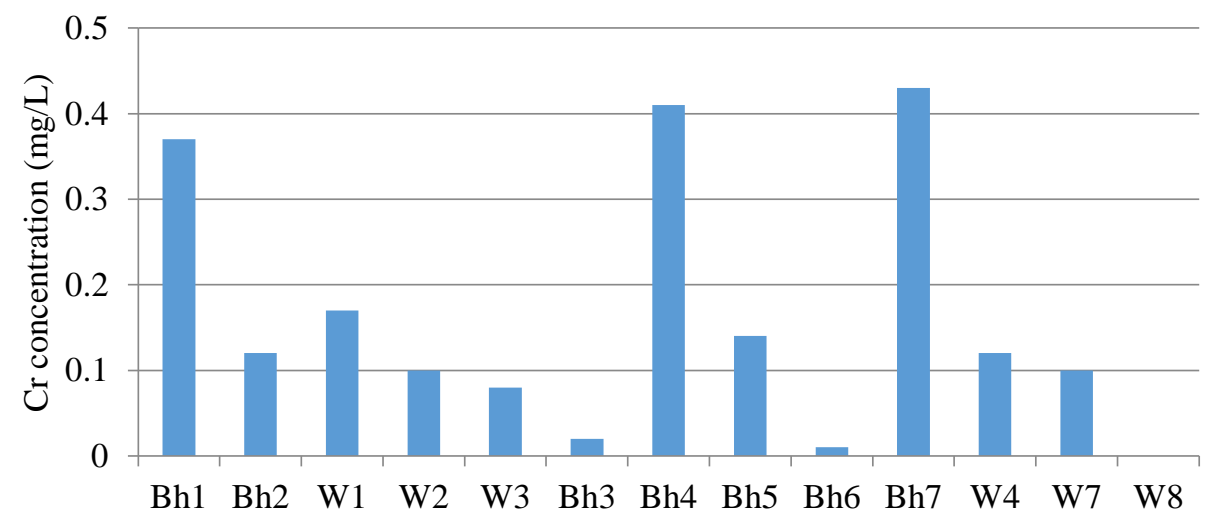

Figure 6: Chromium concentrations in different boreholes and wells

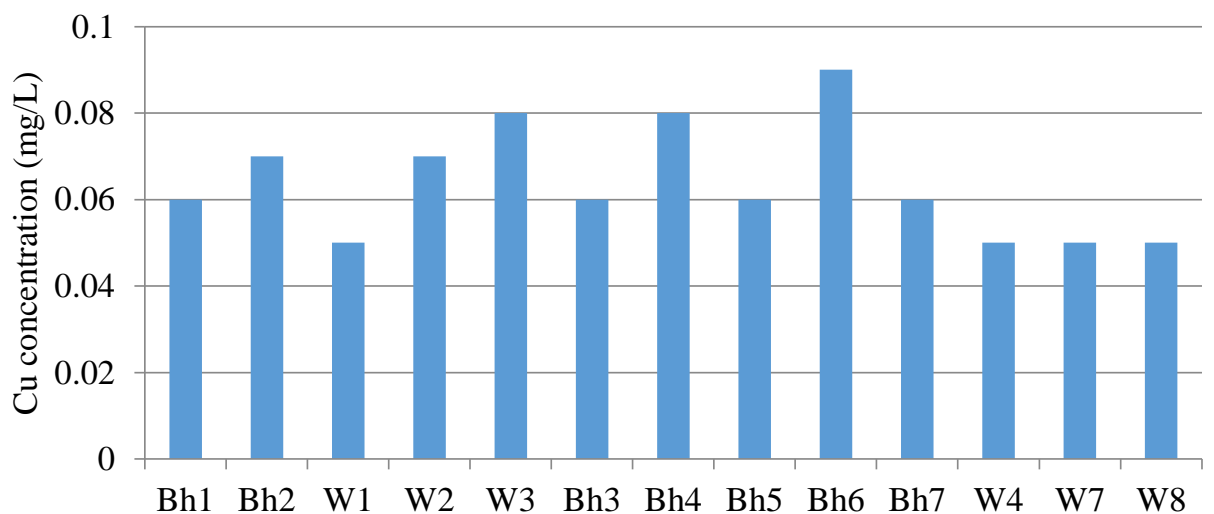

Figure 7: Copper concentrations in different boreholes and wells 
Table 5: Result of water sample of the study area

\begin{tabular}{|c|c|c|c|c|c|c|c|}
\hline $\mathrm{S} / \mathrm{N}$ & Description & $\begin{array}{r}\text { Coorc } \\
\text { (Eastings }\end{array}$ & $\begin{array}{l}\text { linates } \\
\text { Northings) }\end{array}$ & $\begin{array}{c}\mathrm{Cu} \\
(\mathrm{mg} / \mathrm{L})\end{array}$ & $\begin{array}{c}\mathrm{Pb} \\
(\mathrm{mg} / \mathrm{L})\end{array}$ & $\begin{array}{c}\mathrm{Zn} \\
(\mathrm{mg} / \mathrm{L})\end{array}$ & $\begin{array}{c}\mathrm{Cr} \\
(\mathrm{mg} / \mathrm{L})\end{array}$ \\
\hline 1 & Bh3 & 541855.7 & 729887.4 & 0.06 & 0.07 & 2.09 & 0.02 \\
\hline 2 & Bh6 & 541058.2 & 728732.2 & 0.09 & ND & 5.48 & 0.01 \\
\hline 3 & W8 & 542186 & 728149 & 0.05 & 0.04 & 1.43 & ND \\
\hline 4 & W2 & 542550.8 & 728386.3 & 0.07 & ND & 2.79 & 0.10 \\
\hline 5 & W3 & 541938.6 & 729878.2 & 0.08 & 0.09 & 2.66 & 0.08 \\
\hline 6 & W4 & 542270 & 729810 & 0.05 & 0.09 & 1.47 & 0.12 \\
\hline 7 & W7 & 541989 & 727581 & 0.05 & 0.06 & 3.84 & 0.10 \\
\hline 8 & $\mathrm{Bh} 2$ & 542256 & 728493.6 & 0.07 & ND & 4.09 & 0.12 \\
\hline 9 & Bh1 & 542170 & 728462.8 & 0.06 & 0.01 & 1.04 & 0.37 \\
\hline 10 & W1 & 542409.5 & 728447.6 & 0.05 & ND & 1.64 & 0.17 \\
\hline 11 & Bh7 & 542088 & 727755 & 0.06 & 0.10 & 2.36 & 0.43 \\
\hline 12 & Bh5 & 541457.4 & 728671.1 & 0.06 & 0.07 & 1.04 & 0.14 \\
\hline 13 & $\mathrm{Bh} 4$ & 541386.2 & 729469.4 & 0.08 & 0.07 & 4.38 & 0.41 \\
\hline \multirow{2}{*}{ Standards } & \multirow{2}{*}{\multicolumn{3}{|c|}{$\begin{array}{l}\text { NSDWQ } \\
\text { WHO }\end{array}$}} & 1.00 & 0.01 & 3.00 & 0.05 \\
\hline & & & & 2.00 & 0.01 & NS & 0.05 \\
\hline
\end{tabular}

Note. NSDWQ Values are the maximum permitted levels in the Nigerian Standards for Drinking Water Quality, ND- Not detected, NS- Not supplied. WHO values are the maximum permitted levels in the WHO Drinking Water Quality Guideline.

The vulnerability index of the modify DRASTIC L was calculated using sum overlay of the eight parameter and the vulnerability index was classify into three classes, this agrees with (Saidi et al., 2011). However the result shows that $57 \%$ of the study area is moderately vulnerable, $21 \%$ has low vulnerability and $22 \%$ of the area is of high vulnerability. This agrees with the findings of (Majolagbe et al., 2016) who reported a high vulnerability of groundwater pollution in the vicinity of an active dumpsite (Olusosun) in Lagos, Nigeria.

\subsection{Conclusions}

This study has identified Boreholes and Wells in the study areas that are vulnerable to the impact of the landfill site. The seepage of leachates that contains heavy metals into the aquifers pollutes the underground water. When refuse is not separated before deposal, there is little or no control to the amount of toxics leachates that seeps down. Humans have their residential house close to this dumpsite and evidence from laboratory test has shown that some Wells and Boreholes are more contaminated than others. This is directly related to the distance from the landfill site. The quality of health of humans living in this area can be linked to the water they drink and use for other domestic activities. Thus, it is recommended that refuse be separated from source and also separated on the dumpsite to reduce the exposure of residence to contamination.

\section{Acknowledgments}

We appreciate the office of the Surveyor General of Lagos state, Alausa and Nigerian Meteorological Agency (NIMET) for the data.

\section{References}

Al-Adamat, R. A. N., Foster, I. D. L. and Baban, S. M. J. (2003). Groundwater vulnerability and risk mapping for the Basaltic aquifer of the Azraq basin of Jordan using GIS, Remote sensing and DRASTIC. Applied Geography, 23, pp. 303-324.

Albinet, M. and Margat, J. (2007) Groundwater pollution vulnerability mapping. Bulletin du Bureau de Researches Geologiequeset Minieres Bull BRGM, 3(4), pp. 13 - 22. 
Aller, L., Bennett, T., Lehr, J., Petty, R. and Hackett, G. (1987). DRASTIC: A standardized system for evaluating ground water pollution potential using hydrogeologic settings. National Water Well Association, Dublin, Ohio and Environmental Protection Agency, Ada, OK. EPA-600/2-87-035.1987.

Babiker, I. S., Mohammed, M. A. A., Hiyama, T. and Kato, K. (2005). A GIS-based DRATIC model for assessing aquifer vulnerability in Kakamigahara Heights, Gifu Prefecture, central Japan. Sci. Total Environ. 345, pp. 127-140.

Baghvand, A., Nasrabadi, T., Nabibidhendi, G., Vosoogh, A., Karbassi, A. and Mehradadi, N. (2010). Groundwater quality degradation of an aquifer in Iran central desert. Desalination, 260(3), pp. 264275.

Barton, J., Belitewski, B., Busing, J., Jackson, D., Karasek, M. and Kreysa, P. (1994). Technologies for Environmental Protection. 2nd European Recycling Workshop, 29-30 June 1994.

Beynen, P. E., Niedzielski, M. A., Bialkowska-Jelinska, E., Alsharif, K. and Matusick, J. (2012) Comparative study of specific groundwater vulnerability of a karst aquifer in central Florida. Applied Geography, 32, pp. 868-877.

Gupta, N. (2014). Groundwater Vulnerability Assessment using DRASTIC Method in Jabalpur District of Madhya Pradesh. International Journal of Recent Technology and Engineering (IJRTE), 3(3), pp. 36-43.

Jasem, A. H. and Alraggad, M. (2010). Assessing groundwater vulnerability in Azraq basin area by a modified DRASTIC index. Water Resource and Protection, 2, pp. 944-51.

Jhamnani, B. and Singh, S. K. (2009). Groundwater contamination due to Bhalaswa Landfill site in New Delhi. Int. J. Enviorn. Sci. Eng. 1(3), pp. 121-125.

Makinde, E. O. and Tologbonse, A. S. (2017). Oil Spill Assessment InIjeododo Area Of Lagos State, Nigeria Using Geospatial Techniques. Ethiopian Journal of Environmental Studies \& Management, 10(4), pp. 427 - 442. doi:https://dx.doi.org/10.4314/ejesm.v10i4.1.

Marcomini, A., Giove, S., Critto, A., Agostinni, P., Pizzol, L. and Zabeo, A. (2011). Regional risk assessment for contaminated sites Part 1: Vulnerability assessment by multicriteria decision analysis. Environment International, 37, pp. 1295-1306.

Masetti, M., Sorichetta, A. et al., (2011). Reliability of groundwater vulnerability maps obtained through statistical methods. Journal of Environmental Management, 92, pp. 1215-1224.

Muhammad, A. M., Zhonghua, T., Dawood, A. S. and Earl, B. (2015). Evaluation of local groundwater vulnerability based on DRASTIC index method in Lahore, Pakistan. Geofisica Internacional, 54(1), pp.67-81. https://doi.org/10.1016/j.gi. 04.003.

Napolitano, P. and Fabbri, A. G. (1996). Single parameter sensibility analysis for aquifer vulnerability assessment using DRASTIC and SINTACS. In Proceedings of the HydrolGis application of geographic information systems in hydrology and water resources management, ed. K. Kova, and H.P. Nachtnebel,1996. 559-566. Vienna: IAHS.

Omodanisi, E. O., Eludoyin, A. O. and Salami, A. T. (2014). A Multi-Perspective View of the Effects of a Pipeline Explosion in Nigeria. International Journal of Disaster Risk Reduction (IJDRR), 7, pp. 68-77. http://dx.doi.org/10.1016/j.ijdrr.2013.11.002.

Osibanjo, O. and Majolagbe, A. O. (2012). Physicochemical quality assessment of groundwater based on land use in Lagos city, southwest, Nigeria. Chemistry Journal, 2(2), pp. 79-86. 
Oyeku, O. T. and Eludoyin, A. O. (2010) Heavy metal contamination of groundwater resources in a Nigerian urban settlement. African Journal of Environmental Science \& Technology, 4 (4), pp. 201214.

Saidi, S., Bouri, S., Ben Dhia, H. and Anselme, B. (2009). A GIS-based susceptibility indexing method for irrigation and drinking water management planning: Application to Chebba-Mellouleche Aquifer, Tunisia. Agric. Water Manag. 96, pp. 1683-1690.

Schijven, J. F., Hassnizadeh, S. M., Husman, A. M. (2010). Vulnerability of unconfined aquifers to virus contamination. Water Res. 44(4), pp. 1170-1181.

Shirazi, S. M., Akib, S., Salman, F. A., Alengaram, U. J. and Jameel, M. (2010). Agro-ecological aspects of groundwater utilization - A case study. Scientific Research and Essays, 5(18), pp. 27862795.

World Health Organization (WHO) (2013). Global Water Supply and Sanitation Assessment 2000 Report. Available at: http://www.who.int/water_sanitation_health/monitoring/globalassess/en/. 